\title{
RENOPROTECTIVE AND HEPATOPROTECTIVE EFFECTS OF HIPPOCRATEA EXCELSA ON METABOLIC SYNDROME IN FRUCTOSE-FED RATS
}

\author{
ELIZABETH ALEJANDRINA GUZMÁN HERNÁNDEZ ${ }^{1,2 *}$, SILVANA ANDREA DÍAZ \\ PORTILLO $^{1}$, ÓSCAR CRISTÓBAL VILLAFUERTE ANAYA ${ }^{1}$, MARÍA DEL ROSARIO \\ GONZÁLEZ VALLE ${ }^{3}$, JOSÉ DEL CARMEN BENÍTEZ FLORES ${ }^{3}$, RUBÉN SAN MIGUEL \\ CHÁVEZ ${ }^{4}$, GLADYS CHIRINO GALINDO ${ }^{5}$, LEONARDO DEL VALLE MONDRAGÓN ${ }^{6}$, \\ DAVID SEGURA COBOS ${ }^{2}$, GIL ALFONSO MAGOS GUERRERO ${ }^{7}$, PEDRO LÓPEZ SÁNCHEZ ${ }^{1}$
}

\author{
${ }^{1}$ Postgraduate Studies and Research Section, Higher School of Medicine, National Polytechnic Institute, Mexico City, 11340, \\ Mexico \\ ${ }^{2}$ Medical Surgeon Career, Faculty of Superior Studies Iztacala, National Autonomous University of Mexico, Tlalnepantla, \\ State of Mexico, 54090, Mexico \\ ${ }^{3}$ Histology Laboratory, Morphology and Function Unit, Faculty of Superior Studies Iztacala, National Autonomous \\ University of Mexico, Tlalnepantla, State of Mexico, 54090, Mexico \\ ${ }^{4}$ Phytochemistry Area, Postgraduate Degree in Botany, Campus Montecillo, Postgraduate College, Km. 36.5 México-Texcoco \\ Road, Montecillo, Texcoco, State of Mexico, C.P. 56230, Mexico \\ ${ }^{5}$ Biology Career, Faculty of Superior Studies Iztacala, National Autonomous University of Mexico, Tlalnepantla, State of \\ Mexico, 54090, Mexico \\ ${ }^{6}$ Department of Pharmacology, National Institute of Cardiology Ignacio Chávez, Mexico City, C.P. 04510, Mexico \\ ${ }^{7}$ Department of Pharmacology, Faculty of Medicine, National Autonomous University of Mexico, Coyoacán, Mexico City, \\ C.P. 04510, Mexico
}

*corresponding author: shponia2000@yahoo.com.mx

Manuscript received: January 2020

\begin{abstract}
The metabolic syndrome is associated with the development of chronic kidney disease and liver damage. The aim of this research was to determine the effect of the ethanol bark extract of Hippocratea excelsa (HE) on high fructose consumption-induced adverse effects in the kidney and liver of rats. Rats with $20 \%$ fructose feeding for 12 weeks showed arterial hypertension, obesity, dyslipidaemia and developed oxidative stress, proteinuria, the activities of antioxidant enzymes in the renal cortex and liver were decreased, TGF- $\beta 1$ increased, and kidney and liver damage were observed. After the treatment for 6 weeks with HE ( 30 and $100 \mathrm{mg} / \mathrm{kg} \mathrm{bw}$ ) renoprotective and hepatoprotective effects in high fructose induced metabolic syndrome in rats, were demonstrated.
\end{abstract}

\section{Rezumat}

Sindromul metabolic este asociat cu dezvoltarea bolilor renale cronice și a afectării hepatice. Scopul acestei cercetări a fost de a evalua acțiunea extractului etanolic din scoarța de Hippocratea excelsa (HE) asupra efectelor adverse induse de consumul ridicat de fructoză, la nivel renal și hepatic, la șobolani. Șobolanii cu hrana îmbogățită cu 20\% fructoză, timp de 12 săptămâni, au prezentat hipertensiune arterială, obezitate, dislipidemie şi au dezvoltat stres oxidativ, proteinurie. Activităţile enzimelor antioxidante din cortexul renal și ficat au scăzut, TGF- $\beta 1$ a crescut și au fost observate leziuni la nivelul rinichilor și ficatului. După tratarea timp de 6 săptămâni cu HE (30 și $100 \mathrm{mg} / \mathrm{kgc}$ ) s-au observat efecte renoprotectoare şi hepatoprotectoare la șobolanii cărora li s-a indus sindromul metabolic prin consumul ridicat de fructoză.

Keywords: Hippocratea excelsa, kidney disease, metabolic syndrome, liver damage

\section{Introduction}

Metabolic syndrome is a serious threat to public health because it is closely related to the modern lifestyle, diet plays an important role in growth and development as a source of nutrition, but the composition of the diet decides its nutritional status. The modern diet, especially in Western countries, is rich in carbohydrates such as fructose and sucrose as well as saturated fat. This increased caloric intake affects multiple metabolic functions and has been associated with a higher incidence of the metabolic syndrome [1]. Excess weight and obesity are associated with hemodynamic, structural and histological renal and liver changes, in addition to metabolic and biochemical alterations that lead to kidney disease and liver injury [2].

Combinations of carbohydrate and fat-rich dietary components have been used in rodents to mimic these 
signs and symptoms of human metabolic syndrome and his association with renal and liver damage [3]. Hippocratea excelsa HBK. (Hippocrateaceae) (syn.: Hemiangium excelsum $\mathrm{HBK}$ ) is a liana native to Mexico and Central America. The root bark of this plant, known as "Cancerina", is used in the Mexican traditional medicine for the treatment of peptic ulcers, gastrointestinal infections, skin ailments, kidney disease, menstruation disorders and as antihypertensive [4]. Root bark of $H$. excelsa has been widely studied in México for its anti-inflammatory, antiparasite and in vitro anti-tumour effects [5]. H. excelsa, as antiinflammatory agent produced a significant inhibition of carrageenan-induced paw oedema and reduced the weight of cotton pellet-induced granuloma at doses of $25-100 \mathrm{mg} / \mathrm{kg} \mathrm{bw} \mathrm{[5].} \mathrm{H.} \mathrm{excelsa,} \mathrm{for} \mathrm{its} \mathrm{anti-}$ tumour effect, was used in bioscreening studies to detect the cytotoxic activity against human tumour cells in three different extracts (petroleum ether, ethylacetate and methanol) [5]. In the present study, we examined the effect of $H$. excels $a$ administration on liver damage and kidney disease, in a high fructose induced metabolic syndrome rat model.

\section{Materials and Methods}

Preparation and identification of the ethanol extract of H. excelsa

The root bark of H. excelsa was collected on April 2016 at Costa Grande, Guerrero, Mexico and authenticated by Edith López Villafranco, biologist. A voucher specimen (2483) has been deposited at the Herbarium of the Botany Department of the Faculty of Superior Studies Iztacala, National Autonomous University of Mexico (UNAM).

For the in vivo evaluation, powered $H$. excelsa root bark $(3 \mathrm{~kg})$ was extracted twice by maceration with ethanol (30:1 v/w) at room temperature for $72 \mathrm{~h}$, filtered and evaporated in vacuo $\left(50^{\circ} \mathrm{C}\right)$. The dry ethanol extract was stored at $4^{\circ} \mathrm{C}$. The yield of obtaining the ethanol extract of $H$. excelsa (HE) was $6.5 \%$.

\section{Phytochemical profiling}

For the chromatographic analysis of HE it was used a high-resolution liquid chromatograph Hewlett Packard Mod. 1100, equipped with an automatic injector (Agilent Technologies Mod. 1200), a diode array detector (Hewlett Packard Mod. 1100) and a quaternary pump HP Mod. 1100.

Chromatography for the analysis of phenolic acids in HE was performed on a nucleosil 100A 125 x $4 \mathrm{~mm}$ column, adjusted to $30^{\circ}$, using a linear gradient of 1 $\mathrm{mL} / \mathrm{min}$ of water ( $\mathrm{pH} 2.5$ with trifluoroacetic acid) (Solution A) and acetonitrile (solution B). Initially, (0 to $0.1 \mathrm{~min}) 85 \%$ solution $\mathrm{A}$ and $15 \%$ solution $\mathrm{B},(0.1$ to $20 \mathrm{~min}$ ) $65 \%$ solution $\mathrm{A}$ and $35 \%$ solution $\mathrm{B}$ and (20 to $23 \mathrm{~min}$ ) $65 \%$ solution A and $35 \%$ solution B; injection volume: $20 \mu \mathrm{L}$; the phenolic acids were detected at $280 \mathrm{~nm}$.
For the flavonoids in HE, the chromatography was performed on a Hypersil ODS 100A column of $123 \times$ $4.0 \mathrm{~mm}$, adjusted to $30^{\circ}$. The system was operated with gradient elution with solution A: water ( $\mathrm{pH} 2.5)$ with trifluoroacetic acid and solution $\mathrm{B}$ : acetonitrile, with a linear gradient of $1 \mathrm{~mL} / \mathrm{min}$. Initially, (0 to 0.1 min) $85 \%$ solution $\mathrm{A}$ and $15 \%$ solution $\mathrm{B},(0.1$ to 20 min) $65 \%$ solution $\mathrm{A}$ and $35 \%$ solution $\mathrm{B}$ and $(20$ to $25 \mathrm{~min}$ ) $65 \%$ solution $\mathrm{A}$ and $35 \%$ solution $\mathrm{B}$; injection volume: $20 \mu \mathrm{L}$; flavonoids were detected at 254,316 and $365 \mathrm{~nm}$.

The terpenoid analysis was performed with a ZORBAX Eclipse XDB-C8 column (4 mm $\times 125 \mathrm{~mm}, 5 \mu \mathrm{m})$. The major constituents were separated with gradient mobile phase; and the flow was adjusted to $1 \mathrm{~mL} /$ $\min$ for $21 \mathrm{~min}$; that consists of water $20 \%$ and acetonitrile $80 \%$; the detection wavelength of 215 and 220 $\mathrm{nm} ; 20 \mu \mathrm{L}$ injection volume.

In vitro antioxidant capacity

Determination of total phenolic content (TPC). The determination of TPC of the ethanol extract of $H$. excelsa was performed by Folin-Ciocalteu method with little modifications, using gallic acid as a standard phenolic compound [6]. The extract was diluted with distilled water to a known concentration in order to obtain the readings within the standard curve range of 0.0 to $600.0 \mu \mathrm{g}$ of gallic acid $/ \mathrm{mL}$. A volume of $250 \mu \mathrm{L}$ of diluted extract or gallic acid solution was mixed with $1 \mathrm{~mL}$ of distilled water in a test tube followed by the addition of $250 \mu \mathrm{L}$ of Folin-Ciocalteu reagent. The samples were mixed and then allowed to stand for $5 \mathrm{~min}$ at room temperature in order to allow complete reaction with Folin-Ciocalteu reagent. Then $2.5 \mathrm{~mL}$ of $7 \%$ sodium carbonate aqueous solution was added and the final volume was made up to $6 \mathrm{~mL}$ with distilled water. After incubating the samples for $90 \mathrm{~min}$ at room temperature, the absorbance of the resulting blue colour solution was measured at $760 \mathrm{~nm}$ using a spectrophotometer. The result was expressed as $\mathrm{mg}$ of gallic acid equivalents (GAE)/g extract by using an equation that was obtained from standard gallic acid curve. All the experiment was conducted in triplicate.

DPPH radical scavenging assay. The DPPH assay was carried out as described by Hsu et al. with some modifications [7]. A volume of $1.5 \mathrm{~mL}$ of $0.1 \mathrm{mmol} / \mathrm{L}$ DPPH solution was mixed with $1.5 \mathrm{~mL}$ of various concentrations (10 to $500 \mu \mathrm{g} / \mathrm{mL}$ ) of bark extract. The mixture was shaken vigorously and incubated at room temperature for $30 \mathrm{~min}$ in the dark. The reduction of the DPPH free radical was measured by reading the absorbance at $517 \mathrm{~nm}$ by a spectrophotometer. The solution with DPPH and methanol was used as negative control. The experiment was replicated in three independent assays. Quercetin was used as positive control. Inhibition of DPPH free radical in percentage was calculated by the formula: 
FARMACIA, 2020, Vol. 68, 6

DPPH radical scavenging activity $(\%)=\left(\mathrm{A}_{\text {control }}\right.$ -

$$
\left.\mathrm{A}_{\text {test }}\right) / \mathrm{A}_{\text {control }} \times 100 \text {, }
$$

where, $A_{\text {control }}$ is the absorbance of the negative control and $\mathrm{A}_{\text {test }}$ is the absorbance of samples. The antioxidant activity of each sample was expressed in terms of $\mathrm{IC}_{50}$ (micromolar concentration required to inhibit DPPH radical formation by $50 \%$ ), calculated from the graph after plotting inhibition percentage against the extract concentration.

ABTS radical scavenging assay. In order to assess the ABTS radical scavenging assay, the method of Re et al. was adapted [8]. The stock solutions included $7 \mathrm{mmol} / \mathrm{L} \mathrm{ABTS}$ solution and $2.4 \mathrm{mmol} / \mathrm{L}$ potassium persulfate solution. The working solution was then prepared by mixing the two stock solutions in equal quantities and allowing them to react for $12 \mathrm{~h}$ at room temperature in the dark. The resulting solution was then diluted by mixing $1 \mathrm{~mL}$ of freshly prepared ABTS solution to obtain an absorbance of $(0.706 \pm 0.001)$ units at $734 \mathrm{~nm}$ using the spectrophotometer. Fresh ABTS solution was prepared for each assay. The plant extract $(1 \mathrm{~mL})$ was allowed to react with 2.5 $\mathrm{mL}$ of the ABTS solution and the absorbance was registered at $734 \mathrm{~nm}$ after $7 \mathrm{~min}$ using a spectrophotometer. The ABTS scavenging capacity of the extract was compared with that of Trolox and the percentage inhibition was calculated as:

ABTS radical scavenging activity $(\%)=\left(\mathrm{A}_{\text {control }}\right.$ -

$$
\left.\mathrm{A}_{\text {test }}\right) / \mathrm{A}_{\text {control }} \times 100,
$$

where $A_{\text {control }}$ is the absorbance of ABTS radical + methanol; $A_{\text {test }}$ is the absorbance of ABTS radical + sample extract/standard.

Reducing Power Assay (FRAP). For FRAP (ferric reducing antioxidant power) assay, extract/fraction solution $(0.1 \mathrm{~mL})$ was added to reagent $(2 \mathrm{~mL})$ in acetate buffer (0.3 M, pH 3.6), 2,4,6-tris(2-pyridyl)s-triazine (TPTZ) $(10 \mathrm{mM})$ in $40 \mathrm{mM} \mathrm{HCl}$ and ferric chloride $(20 \mathrm{mM})$ in a final ratio of 10:1:1 (v/v/v). Then, the absorbance at $593 \mathrm{~nm}$ was read after 30 min of incubation at room temperature. Similarly, a blank sample (prepared in the same manner, but without the extract) was prepared. Millimoles of Trolox equivalents per gram of ethanolic extract $H$. excelsa (TEs/g extract) were the measurement unit [9].

Ethical consideration and animals used

The study was submitted to the Animal Use Ethics Committee of Faculty of Superior Studies Iztacala, UNAM. It was approved under Protocol No. CE/FESI/ 102016/1110). The handling of the laboratory animals followed the rules for the Care and use of laboratory animals of the Official Mexican Rule (NOM-062ZOO-1999, revised in 2001); the International Guide for Caring and Use of Laboratory Animals NRC 2002; all procedures and experimental protocols are in compliance with the European Communities Council Directive of 24 November 1986 (86/609/EEC).
Thirty male Wistar rats were used, each with a weight of around 200 - $250 \mathrm{~g}$. During the study, the animals were housed in individual stainless steel metabolic cages, measuring $60 \mathrm{~cm} \times 50 \mathrm{~cm} \times 22 \mathrm{~cm}$. They were kept in an air-conditioned environment, with a temperature of $25 \pm 3^{\circ} \mathrm{C}$, and a humidity of $50 \pm$ $10 \%$, a photoperiod of $12 \mathrm{~h}$ of light and dark, and they were fed with standard balanced food ratios for rodents and water ad libitum.

\section{Induction of metabolic syndrome}

The control diet (2018s Teklad Global 18\% protein rodent diet from Harlan Laboratories) contained proteins $(18.6 \%)$, carbohydrates $(44.2 \%)$ and fat (6.2\%). Chow and drinking water with $20 \%$ fructose were elaborated [10]. Rats were initially divided into two groups: control group $(n=6)$ and fructose feed (F) group $(\mathrm{n}=24)$, and treated for 12 weeks under the next conditions: the control group with regular chow and drinking water, and the fructose fed group with $20 \%$ fructose in chow and drinking water.

\section{Experimental design}

After 12 weeks of fructose treatment, the rats were randomly divided into four groups $(n=6)$, were maintained under initial diet conditions and treatments, and were orally administrated for 6 weeks, as follows: Control group; Metabolic syndrome (F); Metabolic syndrome treated with losartan $10 \mathrm{mg} / \mathrm{kg}$ bw (F + Los); Metabolic syndrome group treated with vitamin $\mathrm{E}$ $500 \mathrm{mg} / \mathrm{kg}$ bw (F + Vit E); Metabolic syndrome treated with ethanol extract of $H$. excelsa $(\mathrm{HE}): 30 \mathrm{mg} / \mathrm{kg}$ bw and $100 \mathrm{mg} / \mathrm{kg}$ bw (F + HE 30 and F + HE 100). The HE doses used were based on the toxicity study, the lowest dose that did not present toxic effect (30 $\mathrm{mg} / \mathrm{kg}$ bw and $100 \mathrm{mg} / \mathrm{kg} \mathrm{bw}$ ) were used.

After 6 weeks of treatment, rats were kept in metabolic cages, for evaluating water intake, food intake, and urinary volume at 24 hours; urine samples were used for protein concentration measurement by Bradford method (Bio-Rad) [11].

Blood pressure

Systolic arterial blood pressure (SBP) was measured noninvasively using a tail-cuff computer-aided monitoring device (Automatic Blood Pressure Computer, Model LE 5007; Letica Scientific Instruments, Barcelona, Spain) using the procedures described [12], at the beginning ( 0 week), middle (12 weeks) and end (6 weeks) of the experiment.

Biochemical analyses

Blood concentrations of glucose, total cholesterol and triglycerides were measured using an Accutrend Sensor glucometer (Roche), at the beginning ( 0 week), middle (12 weeks) and end ( 6 weeks) of the experiment.

On the $6^{\text {th }}$ week of treatment, the blood was collected ( $3 \mathrm{~mL}$ ) for the biochemical assessment. High-density lipoprotein (HDL) (Spinreact, Cat. 1001097) and LDLc (Spinreact, Cat. 41023) cholesterol levels, aspartate aminotransferase (AST) (Spinreact, Cat. 12531) and alanine aminotransferase (ALT) (Spinreact, Cat. 12533) 
were measured using commercially available kits following the manufacturer's protocol.

Very-low-density lipoprotein cholesterol (VLDLc) was calculated using the formula: VLDLc $=0.2 \mathrm{x}$ TAG. Cardiac index was calculated as TC/HDLc. Atherogenic index was calculated TC-HDLc/HDLc and coronary artery index was calculated as LDLc/ HDLc [13].

The plasma concentration of angiotensin II, angiotensin (1-7), nitric oxide and endothelin were measured by capillary zone electrophoresis. Plasma was deproteinized with methanol 10:1 (v:v) and centrifuged at 16,000 $\mathrm{x} g$ for $10 \mathrm{~min}$ at $4^{\circ} \mathrm{C}$ (Sorvall RC-28S, rotor SS34; DuPont, Newtown, CT, USA). The pellet was discarded, and supernatant was deproteinized by the addition of $20 \%$ trichloroacetic acid, homogenized and centrifuged at $16,000 \mathrm{xg}$ for $10 \mathrm{~min}$ at $4^{\circ} \mathrm{C}$. The supernatant was filtered through a $0.22 \mu \mathrm{m}$ nitrocellulose membrane filter (Millipore, Billerica, MA, USA) and diluted 1:10 with $0.1 \mathrm{M} \mathrm{NaOH}$. The sample $(2 \mathrm{~mL})$ was then passed through a Sep-Pak Classic C-18 cartridge (Waters Corporation, Milford, MA, USA) as described by $[10,11]$. These experiments were performed using a Beckman Coulter (Fullerton, CA, USA) P/ACE ${ }^{\mathrm{TM}}$ MDQ Capillary Electrophoresis System equipped with PDA and controlled by means of the P/ACE MDQ Capillary Electrophoresis System software (version 7.0; Beckman Coulter Inc., Fullerton, CA, USA) [14, 15].

Histopathological analysis

At the end of the treatments, animals were weighted and anesthetized with sodium pentobarbital (45 mg/ $\mathrm{kg} \mathrm{bw}$, intraperitoneally). The mass of each organ and tissue was measured: kidneys, retroperitoneal adipose tissue and omental adipose tissue. The histopathological analysis of the organs was realized following the technique previously described [16], kidneys and livers were placed in paraformaldehyde $4 \%$, were dehydrated through ethanol graded series, embedded in paraffin, sectioned in $5 \mu \mathrm{m}$ thick slices, mounted on glass slides and stained with haematoxylineosin. Sections of renal cortex further subjected to morphometric analysis 10 adjacent non-overlapping fields from each group were randomly chosen and examined by the light microscope (Leica DMD 108) using a magnification of $40 \mathrm{X}$.

\section{Western blotting assessment}

The kidneys were perfused and rapidly removed. The cortex was isolated before western blotting and enzyme activity measurements. The renal tissue was homogenized in $100 \mathrm{mM}$ Tris (hydroxymethyl-aminomethane-trishydrochloride, Sigma, St Louis, MO, USA), pH 7.4, incubated with a protease-inhibitor cocktail (Complete Mini, EDTA-free protease inhibitor cocktail, Roche, Germany) and centrifuged at $10,000 \times \mathrm{g}$ for $10 \mathrm{~min}$ to remove insoluble debris. Aliquots containing $80 \mu \mathrm{g}$ of protein were separated by reducing $10 \%(\mathrm{w} / \mathrm{v})$ polyacrylamide gel electrophoresis and electroblotted to polyvinylidene difluoride membranes. Coloured molecular weight standards (GE Healthcare, Piscataway, NJ, USA) were run simultaneously. Membranes were blocked for $2 \mathrm{~h}$ in $5 \%(\mathrm{w} / \mathrm{v})$ non-fat milk and incubated overnight in the presence of the corresponding antibodies (rabbit polyclonal antibody to $\mathrm{AT}_{1} \mathrm{R}$, mouse monoclonal antibodies to transforming growth factor beta 1 (TGF- $\beta_{1}$ ) and $\beta$-actin (Santa Cruz Biotechnology Inc., Santa Cruz, California, USA)) (1:1000 dilution) in $5 \%(\mathrm{w} / \mathrm{v}) \mathrm{BSA}$ in phosphate-buffered saline (PBS) containing $0.1 \%(\mathrm{v} / \mathrm{v})$ Tween 20 , at $4^{\circ} \mathrm{C}$. After incubation for $2 \mathrm{~h}$ at room temperature in the presence of the corresponding horseradish-peroxidase-conjugated secondary antibodies (Santa Cruz Biotechnology Inc., Santa Cruz, California, USA) (1:1000 dilution). Complexes were visualized by chemiluminescence detection. Films were scanned, and densitometric analysis was performed using the software Multi Gauge, Fuji Film Science, Lab2003 (Fuji Photo Film Co., LTD).

\section{Evaluation of oxidative stress}

Renal and liver tissue catalase (CAT) activity was assayed at $25^{\circ} \mathrm{C}$, method which is based on the disappearance of $\mathrm{H}_{2} \mathrm{O}_{2}$ from a solution containing $30 \mathrm{mmol} / \mathrm{L} \mathrm{H}_{2} \mathrm{O}_{2}$ in $10 \mathrm{mmol} / \mathrm{L}$ potassium phosphate buffer ( $\mathrm{pH} 7)$ at $240 \mathrm{~nm}$ [17]. The glutathione peroxidase (GPx) activity was assayed by a previously described method [18]. Results were expressed as UI/mg protein. Superoxide dismutase (SOD) activity in renal cortical homogenates was measured by a competitive inhibition assay using xanthine-xanthine oxidase system to reduce NBT [19]. Results were expressed as UI/mg protein. Statistical Analysis

The data represent the mean \pm SEM from 6 rats per treatment. All statistical analyses were performed using GraphPad Prism 5.00 (GraphPad Software, La Jolla, California, USA). C, F, F + Los, F + Vit E, F + $\mathrm{HE} 30$ and $\mathrm{F}+\mathrm{HE} 100$ groups were tested for effects of diet, treatment, and their interactions by twofactor analysis of variance (ANOVA). When the interaction and/or the main effects were significant, means were compared using Tukey's multiple comparison post hoc test.

\section{Results and Discussion}

MS is a progressive health disorder associated with different risk factors, including hyperglycaemia, dyslipidaemia, hypertension and obesity, and that predisposes to cardio-renal dysfunction [20-22]. The chemical composition of the extract of Hippocratea excelsa is presented in Table $\mathrm{I}$. Fructose is a highly lipogenic sugar [22]; the administration of $20 \%$ fructose to rats for 12 weeks induced the classic symptoms of MS; blood triglycerides (TGs), body weight gain, body mass index and abdominal circumference increased, correlated with the increase of weight of total abdominal adipose 
FARMACIA, 2020, Vol. 68, 6

tissue (mesentery, retroperitoneal and epididymal fat) compared to animals with normal diet (Table II and III). Hence, we have used this fructose induced metabolic syndrome rat model [10] to investigate whether the oral administration of ethanol extract of $H$. excelsa (HE) for 6 weeks can reverse the alterations in liver and renal parameters.

Table I

Phytochemical constituents of the ethanol extract of Hippocratea excelsa

\begin{tabular}{|c|c|c|c|}
\hline Retention time (min) & Area $(\mathbf{m A U} * \mathbf{s})$ & Identification & Quantification (\%) \\
\hline 2.502 & 85.00604 & gallic acid & 0.045 \\
\hline 4.420 & 24.63361 & chlorogenic acid & 0.16 \\
\hline 5.491 & 683.4551 & vanillinic acid & 0.11 \\
\hline 6.703 & 500.3157 & caffeic acid & 0.22 \\
\hline 9.416 & 28.79682 & ferulic acid & 0.05 \\
\hline 10.020 & 43.70384 & p-cumaric & 0.03 \\
\hline 4.260 & 6500.446 & oleanolic acid & 1.6 \\
\hline 2.539 & 127.2414 & ursolic acid & 0.26 \\
\hline 6.386 & 110.4542 & $\alpha$-amyrin & 9.3 \\
\hline 6.718 & 23.818 & phloridzin & 0.017 \\
\hline 12.275 & 9.0686 & naringenin & 0.015 \\
\hline 21.428 & 26.4578 & galangin & 0.013 \\
\hline
\end{tabular}

Table II

Effect of fructose feeding over body, plasma, and urinary parameters

\begin{tabular}{|l|c|c|}
\hline \multicolumn{1}{|c|}{ Variables } & Control & Fructose \\
\hline Initial body weight $(\mathrm{g})$ & $231 \pm 4.37$ & $225 \pm 2.99$ \\
\hline Body weight at 12 weeks $(\mathrm{g})$ & $398 \pm 19$ & $436 \pm 10 *$ \\
\hline Body weight gained $(1-12$ weeks) $(\%)$ & $7.2 \pm 1.74$ & $9.4 \pm 1.2$ \\
\hline Body mass index $\left(\mathrm{g} / \mathrm{cm}^{3}\right)$ & $0.89 \pm 0.04$ & $0.88 \pm 0.05$ \\
\hline Abdominal circumference $(\mathrm{cm})$ & $17 \pm 0.58$ & $22 \pm 0.085 *$ \\
\hline Lee index & $0.28 \pm 0.01$ & $0.34 \pm 0.01 *$ \\
\hline Plasma glucose $(\mathrm{mmol} / \mathrm{L})$ & $4.64 \pm 0.48$ & $4.89 \pm 0.24$ \\
\hline Plasma triglycerides $(\mathrm{mmol} / \mathrm{L})$ & $1.044 \pm 0.25$ & $2.72 \pm 0.46 *$ \\
\hline Plasma cholesterol $(\mathrm{mmol} / \mathrm{L})$ & $2.6 \pm 4$ & $2.7 \pm 5$ \\
\hline Urinary volume $(\mathrm{mL})$ & $7 \pm 2$ & $27 \pm 6 *$ \\
\hline Food intake $(\mathrm{g} /$ day) & $20 \pm 2$ & $48 \pm 3 *$ \\
\hline Water intake $(\mathrm{mL} /$ day) & $35 \pm 9$ & $79 \pm 13 *$ \\
\hline Urine protein excretion $(\mathrm{mg} / 24 \mathrm{~h})$ & $27 \pm 4$ & $115 \pm 24 *$ \\
\hline Systolic blood pressure $(\mathrm{mmHg})$ & $116 \pm 15$ & $140 \pm 5 *$ \\
\hline
\end{tabular}

Mean \pm SEM; $n=6$ for control group and $n=30$ for fructose fed group. Statistically significant compared with the control group; $*=p<0.05$

Table III

Effect of HE treatment on metabolic variables in fructose fed rats

\begin{tabular}{|l|c|c|c|c|c|c|}
\hline \multicolumn{1}{|c|}{ Variables } & Control & F & Los & Vit E & HE 30 & HE 100 \\
\hline Food intake (g/day) & $42 \pm 4$ & $14 \pm 5$ & $15 \pm 2$ & $15 \pm 4$ & $16 \pm 4$ & $18 \pm 4$ \\
\hline Water intake (mL/day) & $42 \pm 4$ & $70 \pm 5$ & $66 \pm 8$ & $87 \pm 8$ & $69 \pm 9$ & $76 \pm 10$ \\
\hline Body weight at 18 weeks $(\mathrm{g})$ & $434 \pm 20$ & $572 \pm 19 *$ & $505 \pm 16$ & $491 \pm 31$ & $522 \pm 16$ & $551 \pm 16 *$ \\
\hline $\begin{array}{l}\text { Body weight gained }(12-18 \\
\text { weeks) }(\%)\end{array}$ & $14 \pm 3$ & $30 \pm 2 *$ & $15 \pm 2 \&$ & $16 \pm 2 \&$ & $16 \pm 2 \&$ & $19 \pm 2 \&$ \\
\hline Visceral adiposity index (\%) & $2.53 \pm 0.46$ & $4.93 \pm 0.57 *$ & $3.95 \pm 0.44 *$ & $4.37 \pm 0.68$ & $4.72 \pm 1.13$ & $3.86 \pm 0.30 *$ \\
\hline Body mass index (g/cm 3 ) & $0.73 \pm 0.02$ & $1.05 \pm 0.11 *$ & $0.76 \pm 0.03 \&$ & $0.74 \pm 0.05 \&$ & $0.75 \pm 0.02 \&$ & $0.77 \pm 0.02 \&$ \\
\hline Abdominal circumference (cm) & $19 \pm 0.37$ & $22 \pm 0.6 *$ & $20 \pm 0.32$ & $19 \pm 0.5$ & $20 \pm 0.48$ & $21 \pm 0.48$ \\
\hline Lee index & $0.31 \pm 0.01$ & $0.36 \pm 0.02 *$ & $0.31 \pm 0.01 \&$ & $0.30 \pm 0.008 \&$ & $0.30 \pm 0.003 \&$ & $0.30 \pm 0.004 \&$ \\
\hline Tissue wet weight (mg/mm) & & & & & & \\
\hline $\begin{array}{l}\text { Retroperitoneal adipose } \\
\text { tissue }\end{array}$ & $152 \pm 32$ & $326 \pm 47 *$ & $135 \pm 20 \&$ & $196 \pm 39 \&$ & $148 \pm 12 \&$ & $205 \pm 45 \&$ \\
\hline Omental adipose tissue & $144 \pm 34$ & $255 \pm 40 *$ & $184 \pm 47$ & $138 \pm 23 \&$ & $150 \pm 27 \&$ & $188 \pm 67$ \\
\hline Plasma glucose (mmol/L) & $4.42 \pm 0.30$ & $5.25 \pm 0.23$ & $5.55 \pm 0.24$ & $5.06 \pm 0.12$ & $5.07 \pm 0.04$ & $5.6 \pm 0.22$ \\
\hline Plasma triglycerides (mmol/L) & $1.18 \pm 0.19$ & $2.62 \pm 0.58 *$ & $3.4 \pm 0.28 *$ & $2.53 \pm 0.34 *$ & $2.57 \pm 0.12 *$ & $3.17 \pm 0.55 *$ \\
\hline Plasma cholesterol (mmol/L) & $2.0 \pm 3.7$ & $2.0 \pm 4$ & $2.34 \pm 6$ & $2.5 \pm 5$ & $2.2 \pm 4$ & $2.3 \pm 8$ \\
\hline AST (UI/L) & $6.4 \pm 3$ & $26 \pm 2 *$ & $18 \pm 3 \&$ & $14 \pm 2 \&$ & $16 \pm 3 \&$ & $8.6 \pm 2 \&$ \\
\hline ALT (UI/L) & $9.3 \pm 2$ & $37 \pm 3 *$ & $25 \pm 4 \&$ & $19 \pm 4 \&$ & $21 \pm 3 \&$ & $17 \pm 3 \&$ \\
\hline
\end{tabular}

$\mathrm{F}=$ fructose fed rats; Los $=\mathrm{F}+\operatorname{losartan} 10 \mathrm{mg} / \mathrm{kg}$ bw; Vit E = F + vitamin E $500 \mathrm{mg} / \mathrm{kg}$ bw; HE $30=\mathrm{F}+\mathrm{HE} 30 \mathrm{mg} / \mathrm{kg}$ bw;

HE $100=\mathrm{F}+\mathrm{HE} 100 \mathrm{~m} / \mathrm{kg}$ bw $\mathrm{n}=6 ; *=\mathrm{p}<0.05$ control $v s$. treatment, $\&=\mathrm{p}<0.05$ fructose fed rats $v s$. treatment 
The fructose fed groups treated with losartan, vitamin $\mathrm{E}$ and HE showed lower Lee index, blood triglycerides, weight of retroperitoneal adipose tissue and omental adipose tissue compared with fructose fed animals (Table III). Losartan treatment significantly elevated the serum concentrations of total adiponectin in patients with essential hypertension [23]. In rats, losartan reduced leptin concentration in both losartan and high fat diet and losartan groups [24]. Leptin is released from adipose tissues into the blood stream and regulates appetite, feeding and energy expenditure [24]. Liver functions were evaluated in the rat by determining the serum concentrations of ALT and AST. Activities of AST and ALT are most commonly used as biochemical markers for liver damage. Since these enzymes are cytoplasmic in nature, upon liver injury these enzymes enter into the circulatory system due to altered permeability of membrane [25]. As shown in Table III, serum levels of AST and ALT were significantly increased after 18-weeks of high fructose feeding ( $\mathrm{p}$ $<0.05)$ [26]; HE significantly prevented high fructose induced elevation of AST and ALT, indicating the hepatoprotective activity of HE. Oral treatment with $\alpha$-amyrin $(20 \mathrm{mg} / \mathrm{kg} \mathrm{bw})$, a pentacyclic triterpenoid that is a component of $\mathrm{HE}$, attenuated the increase of AST and ALT enzymes activities in a rat model of $\mathrm{CCl}_{4}$-induced hepatic oxidative stress and a subsequent recovery towards normalization of these enzymes [27].
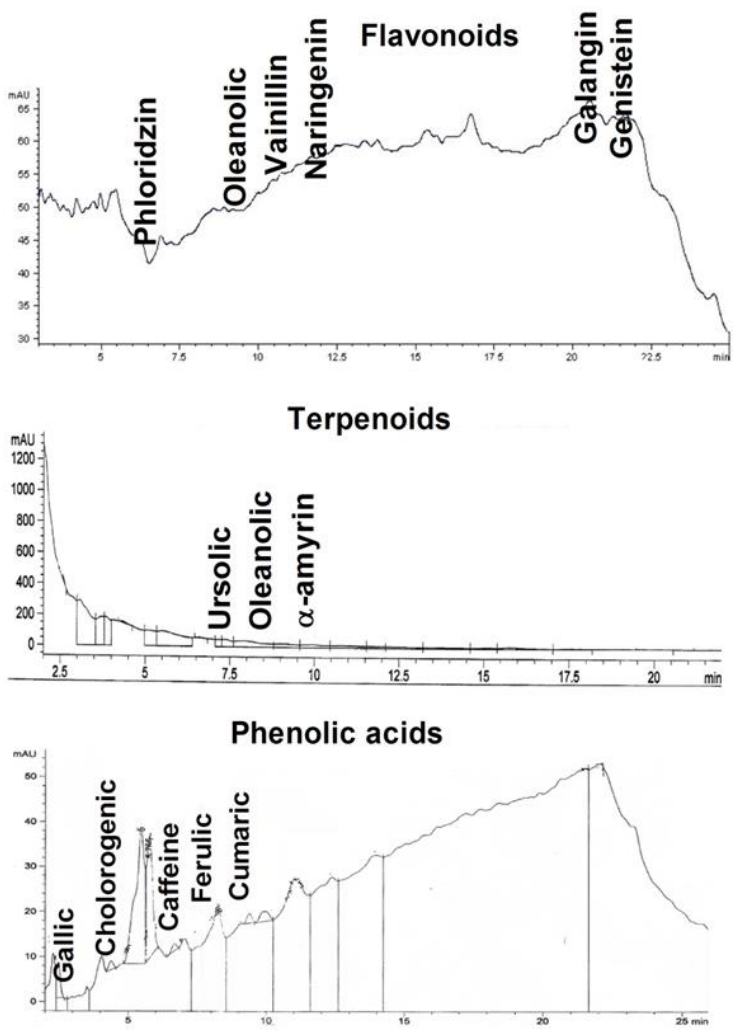

Figure 1.

Chromatographic profile of root bark ethanol extract of $H$. excelsa
The chromatographic profile of $\mathrm{HE}$ revealed the presence of several phytoconstituents (Figure 1 and Table I): $\alpha$-amyrin, oleanolic acid, ursolic acid, caffeic acid, and chlorogenic acid. The components of HE: $\alpha$ amyrin and oleanolic acid, cause the effects attributed to $H$. excelsa. Alpha-amyrin treatment prevented the increase in blood triglycerides [28], weight of retroperitoneal adipose tissue and omental adipose tissue [29], observed effects in HE treated groups in this work (Table III).
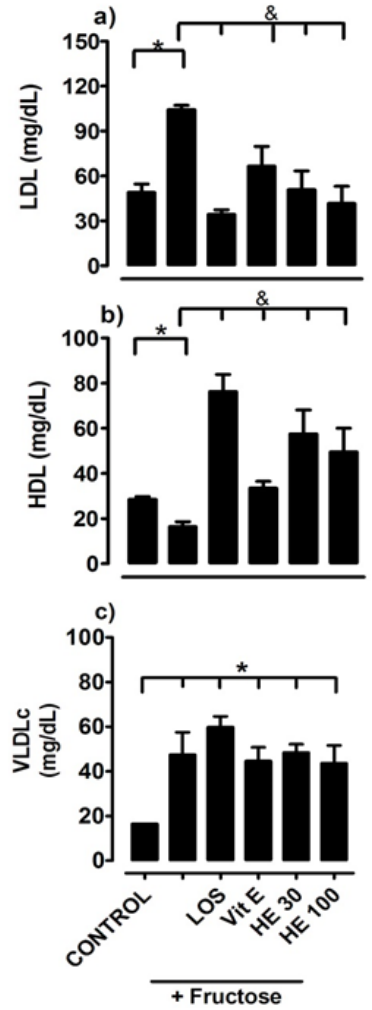
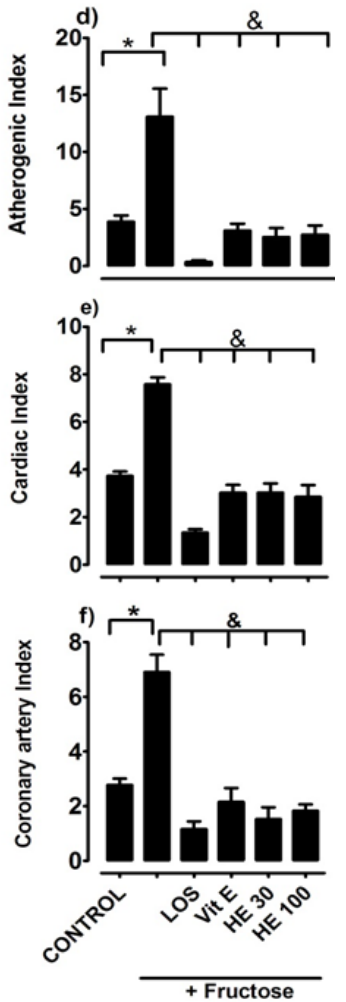

Figure 2.

Lipid profile: (a) LDL, (b) HDL, (c) VLDL and (d) atherogenic, (e) cardiac and (f) coronary artery indexes in rats with fructose induced metabolic syndrome after six weeks of administration of ethanol extract of $H$. excelsa (HE)

$*=\mathrm{p}<0.05$ control $v s$. treatment $\&=\mathrm{p}<0.05$ MetS $v s$. treatment: Control, fructose fed rats (F), F + losartan (Los), $\mathrm{F}+$ vitamin $\mathrm{E}$ (Vit E), F + HE $30 \mathrm{mg} / \mathrm{kg}$ bw (HE 30) and $\mathrm{F}+\mathrm{HE} 100 \mathrm{mg} / \mathrm{kg}$ bw (HE 100)

Impact of treatment with HE on lipid profile

Dietary fructose in the liver is rapidly taken up by the liver, where it can be converted to glycerol-3phosphate, favouring the esterification of unbound fatty acids to form TGs [30]. Hypertriglyceridemia occurs following 12 weeks of consumption of fructose, marked by elevated levels of plasma triglycerides; VLDLc and LDLc in rats with MS increased significantly $(\mathrm{p}<0.05)$ compared with the control (Figures $2 \mathrm{a}$ and 2c). Conversely, the HDLc significantly lowered (Figure 2b); these alterations are features of atherosclerosis and cardiovascular disease [31]. These changes 
in rats with MS were attenuated by $\mathrm{HE}$ compared with losartan and vitamin E treated groups (Figures 2a and 2c). Furthermore, calculated atherogenic, cardiac and coronary artery indexes were increased in rats with MS compared with the control (Figure 2d); administration of losartan, vitamin $\mathrm{E}$ and $\mathrm{HE}$ in fructose fed rats, reversed the increases in these indexes (Figures 2d, 2e and 2f). The attenuation of decrease of HDLc by HE (Figure 2b) shows its ability to prevent the development of atherosclerosis [32]. Oleanolic acid reduced serum triglycerides, total cholesterol, and LDL cholesterol [33]. Chlorogenic acid reduced total cholesterol and LDL-cholesterol, increased HDL cholesterol, and improved both the atherogenic index and the cardiac risk factor, to inhibit fatty acid synthase and hydroxyl methyl glutaryl coenzyme A reductase [34]. Alpha-amyrin reduced serum triglycerides, total cholesterol, LDL-cholesterol, atherogenic index, and increased HDL cholesterol [28]. Antihypertensive effect of $H E$

In the fructose-fed rats, the systolic blood pressure (SBP) was increased compared with the control (148 \pm $3 \mathrm{mmHg}$ for MS group compared with $106 \pm 2 \mathrm{mmHg}$ in control group); this increase was prevented by losartan $(115 \pm 3 \mathrm{mmHg})$ and $\mathrm{HE} 30 \mathrm{mg} / \mathrm{kg}$ bw $(119 \pm 3$ $\mathrm{mmHg}$ ). Increase in SBP after chronic fructose feeding was partially abolished with $\mathrm{HE} 100 \mathrm{mg} / \mathrm{kg}$ bw treatment $(130 \pm 6 \mathrm{mmHg}$ ) (Figure 3).

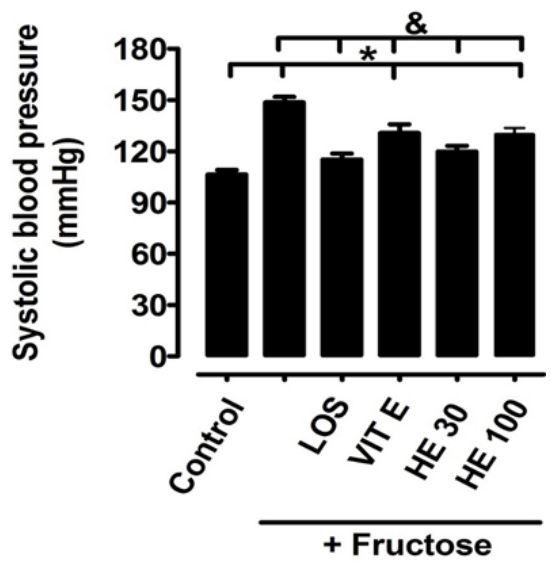

Figure 3.

Effect of the ethanol extract of $H$. excelsa (HE) on systolic blood pressure of fructose fed rats $(F) 6$ weeks after the establishment of metabolic syndrome

Values are the mean $\pm \operatorname{SEM}(\mathrm{n}=6) ; *=\mathrm{p}<0.05$ control vs. treatment; $\&=\mathrm{p}<0.05 \mathrm{~F}$ vs. treatment: $\mathrm{F}+$ losartan (Los), F + vitamin E (Vit E), F + ethanolic extract of $H$. excelsa (HE) $30 \mathrm{mg} / \mathrm{kg}$ bw (HE 30) and $\mathrm{F}+$ ethanolic extract of $H$. excelsa 100
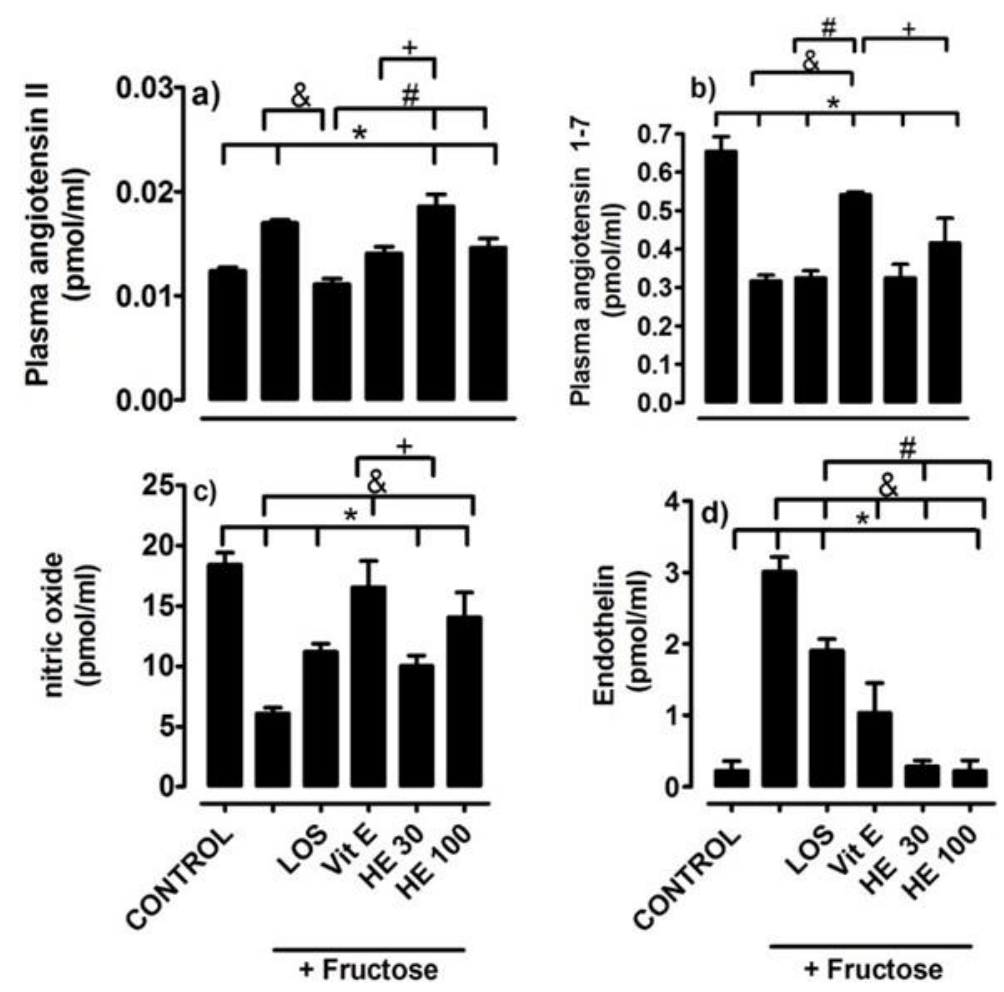

Figure 4.

Effect of ethanol extract of H. excelsa (HE) on the plasma level of (a) angiotensin II, (b) angiotensin 1-7, (c) nitric oxide and (d) endothelin in fructose fed rats $(\mathrm{F})$

All values are represented as mean $\pm \mathrm{SEM} ; \mathrm{n}=6 ; *=\mathrm{p}<0.05$ control $v$ s. treatment; $\&=\mathrm{p}<0.05 \mathrm{~F}$ vs. treatment: $\mathrm{F}+$ losartan $(\operatorname{Los}) ; \#=\mathrm{p}<0.05$ Los vs. treatment; $+=\mathrm{p}<0.05$ Vitamin E (Vit E) vs. treatment, F + HE 30 and HE 100

The administration of fructose decreased the systemic synthesis of vasodilator NO and Ang 1-7 with an increase of vasoconstrictor endothelin 1 (Figures $4 \mathrm{a}$ $4 c)$; this effect was associated with increase in the 
SBP at 12 weeks of fructose fed, as has been shown by other authors $[10,35]$. The compression of kidney by the adipose tissue around it causes activation of the RAS [36]. The activation of RAS causes retention of sodium and water by angiotensin II and leads to the development of hypertension. The pharmacological inhibition of RAS reduced blood pressure to about $50 \%$ to $60 \%$ (Figure 3) [32-35, 37]. The administration of $\mathrm{HE}$ prevented the increase of SBP induced by administration of fructose, so the release of angiotensin 1-7 and release of NO seems to be one mechanism of action in the anti-hypertensive effect of HE (Figure 4d).

Histopathological study

In this study, we found that fructose feeding conducted to kidney hypercellularity (gh), which is an indicator of proliferative glomerulonephritis associated with degenerative changes, atrophy characterized by decrease in kidney size, number of renal corpuscles per field and thickness of the cortex, necrosis, thyroidization and protein deposits located in the proximal convoluted tubule (TCP) and in the space of the Bowman's capsule (Figures 5a and 5d).

Pathologically, kidney damage is characterized by a number of structural changes of kidney cells including a decreased GFR that can lead to the development of glomerulosclerosis and tubulointerstitial fibrosis $[38,39]$. Distortion in the architecture of the cortex and medulla and the significant reduction of the glomerulus diameter suggest sclerosis in the MS of the current study. All these events observed in fructose fed rats were partially ameliorated by treatment with $\mathrm{HE}$ in doses of 30 and $100 \mathrm{mg} / \mathrm{kg}$ bw and renal corpuscles showed a diffuse mild hypercellularity (Figures 6e and 6f).
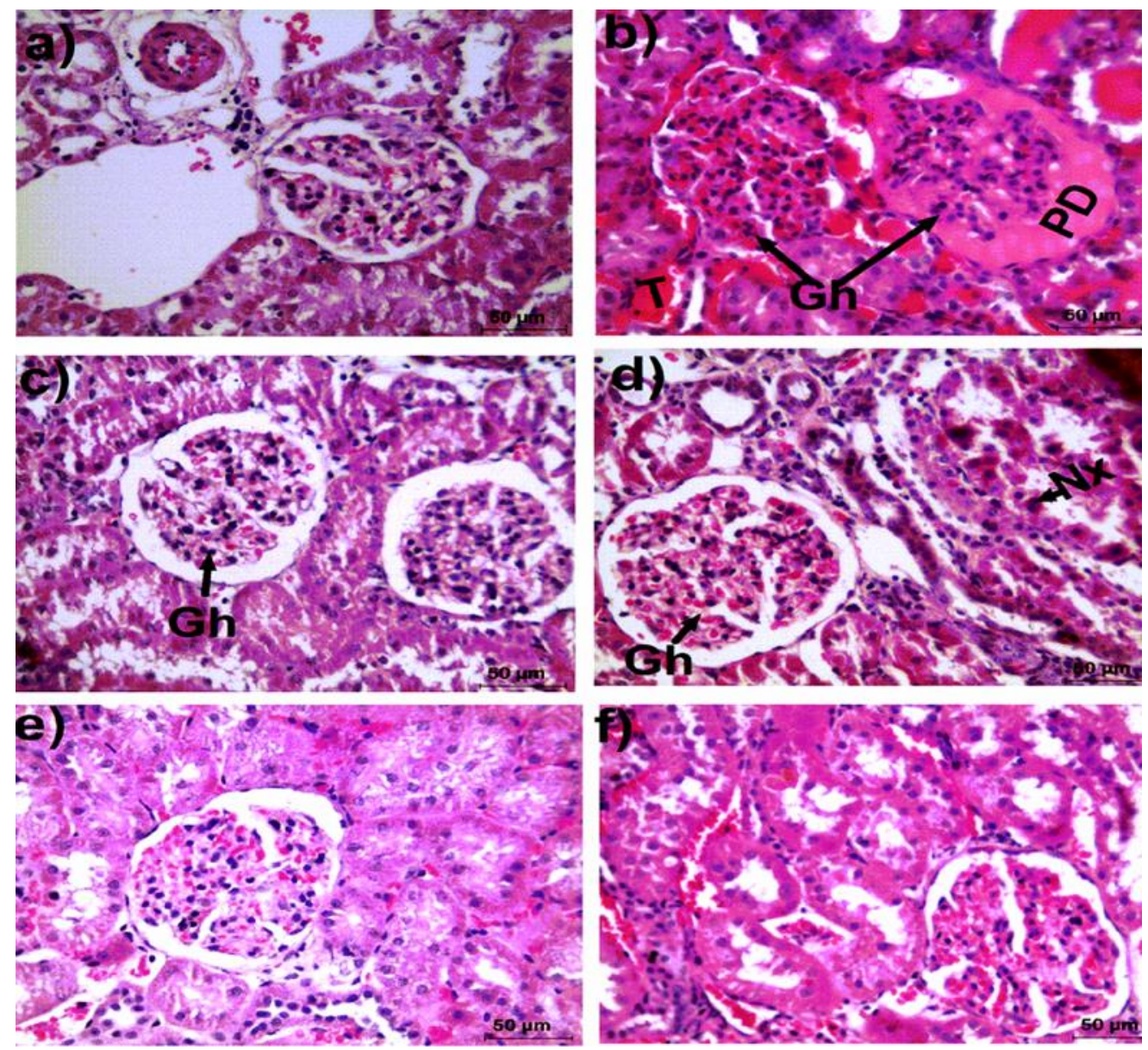

Figure 5.

Photomicrographs (40X magnification) showing histopathological changes in different groups, (a) control. Note that the group treated with fructose (b) is the one that presents the most notorious changes, in this group, the changes were diagnosed as moderate diffuse extension proliferative glomerulonephritis, hypercellularity (Gh), protein deposits (pd) in the Bowman capsule space, obliterated capillary lumen. In the rest of the groups, lighter and multifocal changes were identified. (c) In F + losartan treated group glomerulus only presents hypercellularity (Gh) and the capillary lumen is not obliterated. (d) In F + vitamin E treated group, glomeruli present hypercellularity (GH), multifocal extension. (e) and (f) In F + ethanolic extract of Hippocratea excelsa

(HE) treated group, the kidney has an almost normal appearance 

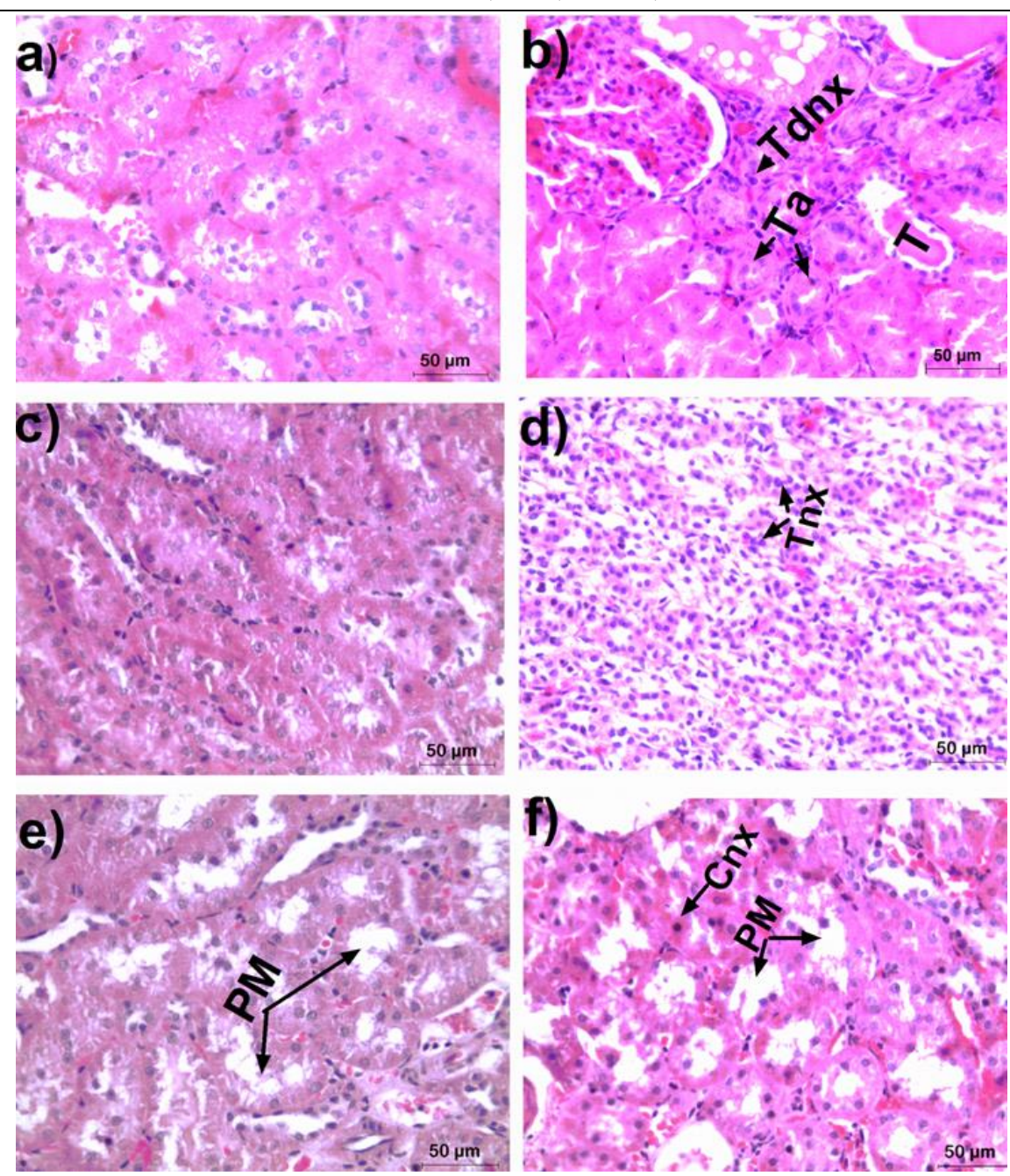

\section{Figure 6.}

Photomicrographs (40X magnification) of contoured tubules in the different groups. Control group (a). Note that in the group treated with fructose (b), the most affected tubules correspond to the distal tubules (TCDnx), in them we find multifocal changes that consist of dilatation that is due to thyroidization, tubular atrophy (Ta) and necrosis. In the group treated with F + vitamin E (d), tubules with degenerative and necrotic changes of multifocal distribution are identified. In the fructose groups treated with losartan (c), HE 30 and HE 100 (e and f), the tubules only show the loss of microvilli, but the tubular arrangement and cellular vitality is maintained $(\mathrm{Cn})$; in them, only some cells suggest necrosis $(\mathrm{Cn})$

At the hepatic level, the MS group exhibited cellular degeneration, massive fatty changes, cytoplasmic vacuolation and the loss of cellular boundaries (Figure $7 \mathrm{~b})$. The liver displayed near normal appearance with well-preserved cytoplasm and prominent nuclei (Figures $7 \mathrm{e}$ and $7 \mathrm{f}$ ); renoprotective and hepatoprotective effect of $\mathrm{HE}$ was demonstrated in an experimental model of metabolic syndrome on rats.

We found that the fructose-treated rats showed renal dysfunctions such as reduced kidney weight, diminished number of renal corpuscles per field and proteinuria (Table IV).

Table IV

Effect of ethanol extract of $H$. excelsa (HE) over renal parameters in fructose fed rats

\begin{tabular}{|l|c|c|c|c|c|c|}
\hline \multicolumn{1}{|c|}{ Variables } & Control & $\mathrm{F}$ & Los & Vit E & HE 30 & HE 100 \\
\hline Kidney weight $(\mathrm{g})$ & $1.32 \pm 0.035$ & $1.21 \pm 0.03 *$ & $1.45 \pm 0.04$ & $1.3 \pm 0.07$ & $1.32 \pm 0.024$ & $1.28 \pm 0.03$ \\
\hline Rat body weight ratio $(\mathrm{mg} / \mathrm{g})$ & $2.79 \pm 0.10$ & $2 \pm 0.086^{*}$ & $2.74 \pm 0.15 \&$ & $2.59 \pm 0.17 \&$ & $2.54 \pm 0.09 \&$ & $2.38 \pm 0.04 \&$ \\
\hline Thickness of the cortex $(\mu \mathrm{m})$ & $2721 \pm 50$ & $2185 \pm 90^{*}$ & $2355 \pm 22 \&$ & $1946 \pm 103 *$ & $2415 \pm 39 \&$ & $2453 \pm 33 \&$ \\
\hline $\begin{array}{l}\text { Number of renal corpuscles } p e r \\
\text { field }(10 \mathrm{X})\end{array}$ & $9 \pm 0.4$ & $5.7 \pm 1.0 *$ & $7.5 \pm 0.85 \&$ & $4.5 \pm 0.5 *$ & $8 \pm 1.4 \&$ & $7.5 \pm 0.95 \&$ \\
\hline Proteinuria $(\mathrm{mg} / 24 \mathrm{~h})$ & $17 \pm 6$ & $89 \pm 14^{*}$ & $32 \pm 2 \&$ & $31 \pm 4 \&$ & $37 \pm 8 \&$ & $31 \pm 5 \&$ \\
\hline
\end{tabular}

$\mathrm{F}=$ rats with fructose induced metabolic syndrome; $\mathrm{Los}=\mathrm{F}+$ losartan; Vit $\mathrm{E}=\mathrm{F}+$ vitamin $\mathrm{E} ; \mathrm{HE} 30=\mathrm{F}+\mathrm{HE} 30 ; \mathrm{HE} 100=\mathrm{F}+\mathrm{HE} 100 ; \mathrm{n}$ $=6 ; *=\mathrm{p}<0.05$ control $v s$. treatment; $\&=\mathrm{p}<0.05 \mathrm{~F} v s$. treatment 

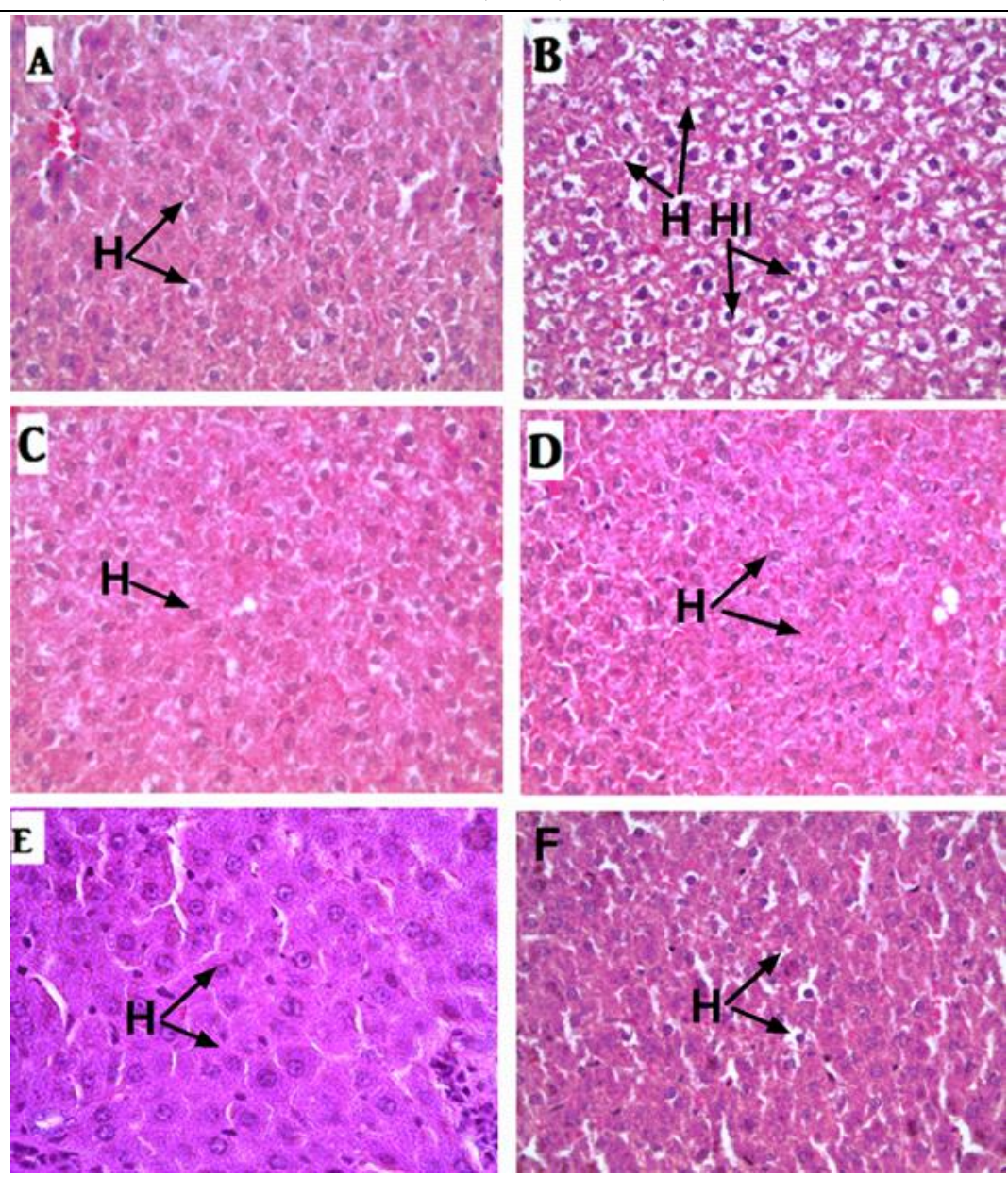

\section{Figure 7.}

Representative haematoxylin and eosin (H\&E) staining photos of liver tissue (40X magnification) showing histopathological changes in different groups: (A) control; (B) metabolic syndrome (F); (C) F+ losartan treated group, (D) In F + vitamin E treated group, (E and F) In F + ethanolic extract of Hippocratea excelsa (HE) treated group
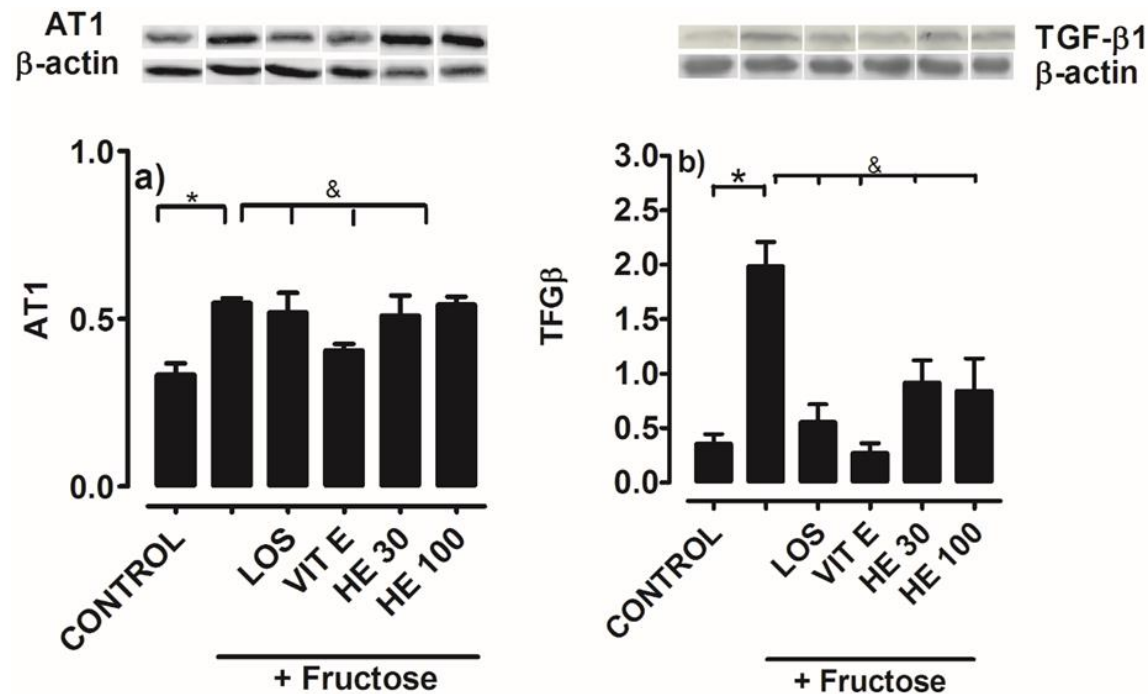

Figure 8.

Effect of ethanol extract of $H$. excelsa (HE) on the expression of (a) AT1R and (b) TGF- $\beta 1$ proteins in renal cortex of rats with fructose induced metabolic syndrome $(\mathrm{F})$

$\mathrm{F}=$ fructose; $\mathrm{Los}=\mathrm{F}+$ losartan; Vit $\mathrm{E}=\mathrm{F}+$ vitamin $\mathrm{E} ; \mathrm{HE} 30=\mathrm{F}+\mathrm{HE}$ 30; HE $100=\mathrm{F}+\mathrm{HE} 100$

Values are expressed as mean $\pm \mathrm{SEM} ; \mathrm{n}=5 ; *=\mathrm{p}<0.05$ control $v s$. treatment; $\&=\mathrm{p}<0.05 \mathrm{~F} v$ s. treatment 
These findings are in line with previous studies demonstrating that high fructose resulted in proteinuria $[13,34]$. The overexpression of TGF- $\beta 1$ in the rat glomeruli induces proteinuria [40]. However, the parameters of kidney function in the fructose fed rats treated with $H$. excelsa were comparable to those of the control rats; these results demonstrate that $H$. excelsa slowed the progression of functional and structural damage to the kidney in fructose-fed rats. Inappropriate activation of renin-angiotensin aldosterone system (RAS) is a pathophysiologic factor in the link between hypertension and metabolic syndrome [41]; the profibrogenic cytokine TGF- $\beta 1$ participates in kidney damage in high fructose induced MS [42-44]. In this study, it was found an elevated expression of AT1R and TGF- $\beta 1$ in MS compared to the lean controls (Figures $8 \mathrm{a}$ and $8 \mathrm{~b}$ ). Conversely, HE treatment did not change the expression of AT1R, (Figure 8a) and decreased TGF- $\beta 1$ protein expression (Figure $8 b$ ).

It has been shown that local RAS is significantly upregulated during liver fibrosis where angiotensin II stimulates contraction and proliferation of the activated hepatic stellate cells and increases the expression of TGF- $\beta 1$ through angiotensin II type 1 receptors [45]. The present results showed that losartan and extract of bark of $H$. excelsa treatments significantly alleviated the histological injury of liver, displaying near normal appearance with well-preserved cytoplasm and prominent nuclei (Figure 7); hepatoprotective effect of HE was demonstrated in an experimental model of metabolic syndrome on rats [46].

Antioxidant capacity in vitro

Other mechanisms involved in renal and liver damage are concerning oxidative stress. Fructose consumption increases levels of lipid peroxides and decreases activities of antioxidant enzymes in the kidney and liver [47, 48]. High fructose produces reactive oxygen species (ROS) in vitro and in vivo. In this study was determined the antioxidant activity in vivo and in vitro of the ethanol extract $H$. excelsa.

In the present study, $H$. excelsa bark extract possessed high phenolic contents (286.4 mg GAE/g of extract), was calculated using the standard curve of gallic acid (standard curve equation: $\mathrm{Y}=11.747 \mathrm{x}+0.0262$, $\left.\mathrm{R}^{2}=0.998\right)$. Other plant that showed relevant antioxidant and medicinal properties is Buddleja cordata; the methanol extract of $B$. cordata showed $177.13 \pm$ $1.97 \mathrm{mgEq}$ gallic acid/g, which presented $17.71 \%$ phenolic compounds in the extract; $B$. cordata showed antioxidant and neuroprotective effects in the 1methyl-4-phenylpyridinium Parkinson disease rat model [49, 50].

DPPH radical scavenging assay

It is well known that the antioxidant activity of plant extracts containing polyphenol components is due to the capacity to be donors of hydrogen atoms or electrons and to capture the free radicals [51]. In the present study, $H$. excelsa ethanolic bark extract showed a significant effect in inhibiting DPPH, reaching up to $88 \%$ at concentration of $50 \mu \mathrm{g} / \mathrm{mL}$, showing a dose response curve of DPPH radical scavenging activity of $H$. excelsa compared with standard quercetin. The $\mathrm{IC}_{50}$ value of $H$. excelsa extract was $18.05 \mu \mathrm{g} / \mathrm{mL}$ while the $\mathrm{IC}_{50}$ value of standard antioxidant quercetin was $5.3 \mu \mathrm{g} / \mathrm{mL}$. The DPPH assay is one of the most widely used methods for screening the antioxidant activity of plant extracts. The antioxidant plant, $B$. cordata showed an $\mathrm{IC}_{50}$ value of $64.19 \pm 2.09 \mu \mathrm{g} /$ $\mathrm{mL}$ [51].

ABTS radical scavenging activity

The ethanolic bark extract of $H$. excels $a$ were fast and effective scavengers of the ABTS radical and this activity was comparable to that of BHT. It exhibited potent scavenging effects against ABTS with an $\mathrm{IC}_{50}$ value of $21.73 \mu \mathrm{g} / \mathrm{mL}$ almost equivalent to that of standard Trolox $\left(\mathrm{IC}_{50}\right.$ value $5.3 \mu \mathrm{g} / \mathrm{mL}$ ) [48]. The percentage of inhibition was $99 \%$ for the bark extract at $70 \mu \mathrm{g} / \mathrm{mL}$ concentration. Another root extract with antioxidant and hepatoprotective properties, the extract of Pueraria thunbergiana Benth. showed an $\mathrm{IC}_{50}$ value of $138.0 \pm 2.7 \mu \mathrm{g} / \mathrm{mL}$ [53]

The reducing power of $\mathrm{Fe}^{2+}$ by the tested plant was evaluated. The radical scavenging activity of the plant extract showed a concentration-dependent reducing power of $379.23 \mu \mathrm{g} / \mathrm{ET} / \mathrm{g} / \mathrm{extract}$, compared to standard Trolox [49].

Antioxidant enzymes

Oxidative stress is a well-recognized phenomenon playing an important role in the pathogenesis of endothelial dysfunction, hypertension, inflammation and atherosclerotic cardiovascular disease. It is defined as an impaired balance between free radical production and endogenous antioxidant capacity, resulting in the accumulation of oxidative products [13].

The SOD, catalase and GPx activities in renal cortex and liver were reduced in fructose fed rats compared with control group (Figures 9a and 10a); administration of the ethanol bark extract of $H$. excelsa effectively prevented the decrease of SOD, CAT, and GPx (p < 0.05 , respectively).

These results indicated that ethanol extract of bark of $H$. excelsa exerted protective effects against kidney and hepatic injury induced by high fructose diet, at least in part, through decreasing oxidative stress (Figures 9b and 9c); (Figures 10b and 10c), through enhancing ROS-detoxifying enzymes, possibly by activating redox transcription factors as nuclear factor erythroid 2 (Nrf2), perhaps by effect of oleanolic acid [54]. It has been shown that oleanolic acid inhibited oxidative stress and activated heme oxygenase 1 (HO-1)/Nrf2 [54]. 

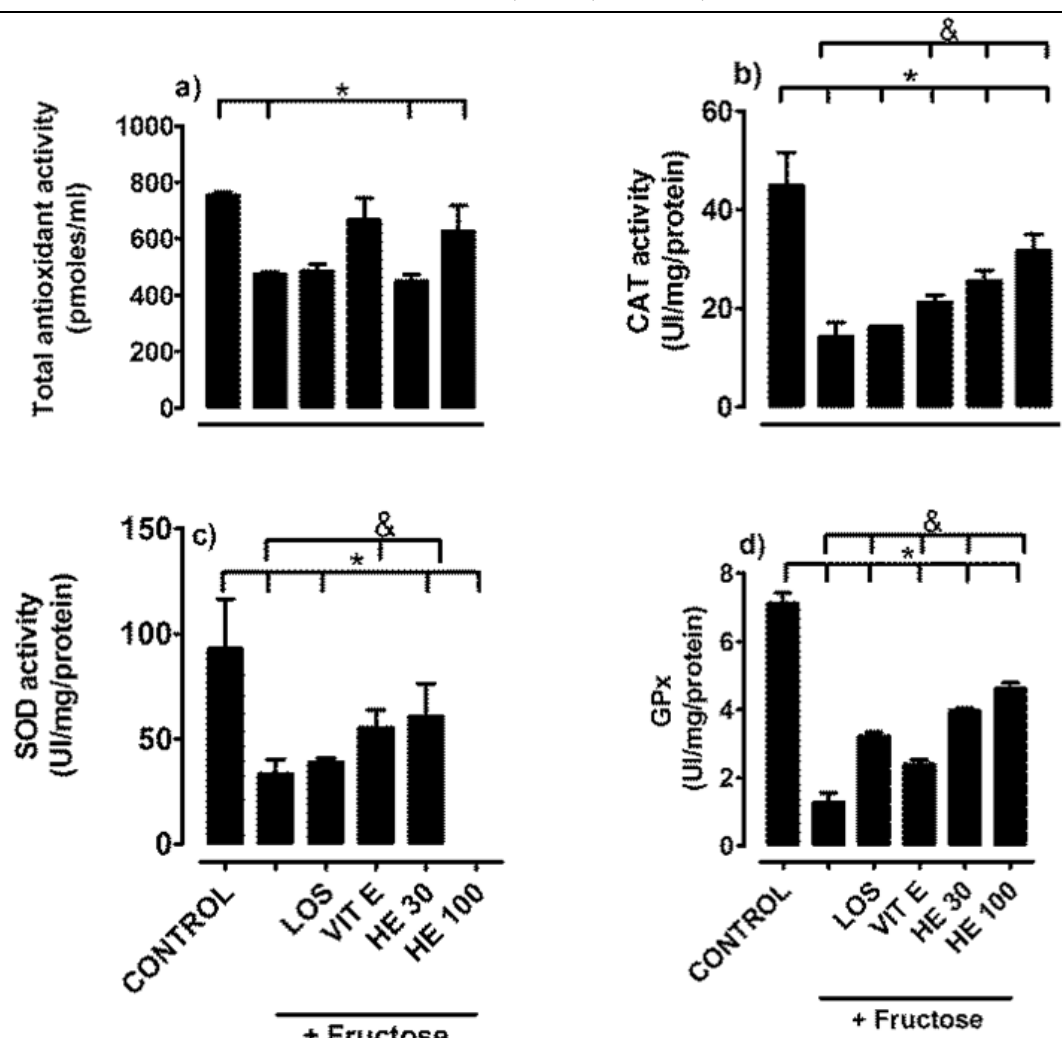

Figure 9.

Effects of ethanolic extract of $\mathrm{H}$. excelsa (HE) on antioxidant enzymes in fructose induced metabolic syndrome rats (F). Plasma total antioxidant activity (a), renal cortical catalase (CAT) (b), superoxide dismutase (SOD) (c) and glutathione peroxidase activities (GPx) (d)

Los $=\mathrm{F}+$ losartan; Vit E = F + vitamin E; HE $30=\mathrm{F}+\mathrm{HE} 30 ; \mathrm{HE} 100=\mathrm{F}+\mathrm{HE} 100$

All values are represented as mean $\pm \mathrm{SEM} ; \mathrm{n}=5 ; *=\mathrm{p}<0.05$ control $v$ s. treatment; $\&=\mathrm{p}<0.05 \mathrm{~F} v s$. treatment

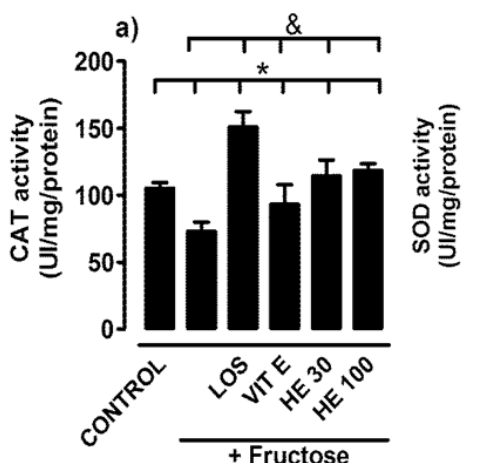

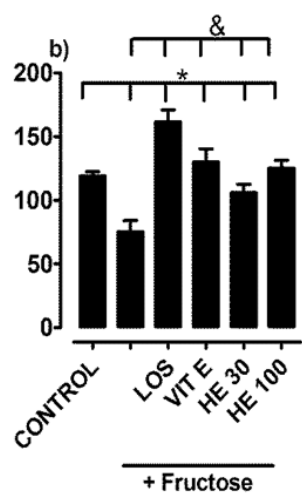

Figure 10.

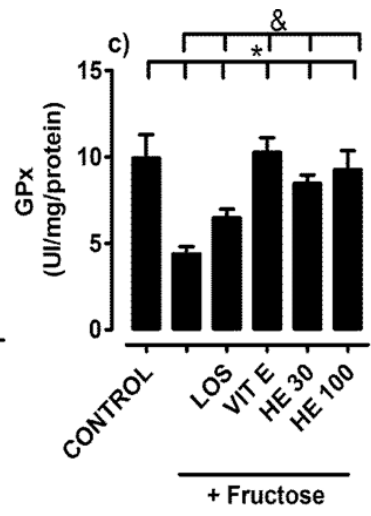

+ Fructose

Effects of ethanolic extract of $\mathrm{H}$. excelsa (HE) on antioxidant enzymes in fructose induced metabolic syndrome rats (F). Hepatic catalase (CAT) (b), superoxide dismutase (SOD) (c) and glutathione peroxidase activities (GPx)

Los $=\mathrm{F}+$ losartan; Vit E = F + vitamin E; HE $30=\mathrm{F}+\mathrm{HE} 30 ; \mathrm{HE} 100=\mathrm{F}+\mathrm{HE} 100$

All values are represented as mean $\pm \mathrm{SEM} ; \mathrm{n}=5 ; *=\mathrm{p}<0.05$ control $v s$. treatment; $\&=\mathrm{p}<0.05 \mathrm{~F}$ vs. treatment

\section{Conclusions}

The ethanol extract of $H$. excelsa showed nephroprotective and hepatoprotective effects by decreasing of arterial hypertension, dyslipidaemia, proteinuria and the expression of TGF- $\beta 1$.

\section{Acknowledgement}

This work was supported by National Council for Science and Technology (México) and Mexican Council of Science and Technology (2016), fellowship to Elizabeth Alejandrina Guzmán Hernández as part of his post-doctoral research. 
Conflict of interest

The authors declare no conflict of interest.

\section{References}

1. McArdle MA, Finucane OM, Connaughton RM, McMorrow AM, Roche HM, Mechanisms of obesityinduced inflammation and insulin resistance: Insights into the emerging role of nutritional strategies. Front Endocrinol., 2013; 4: 52: 1-23.

2. Pommer W, Preventive Nephrology: The Role of Obesity in Different Stages of Chronic Kidney Disease. Kidney Dis (Basel), 2018; 4(4): 199-204.

3. Pashova-Stoyanova L, Tolekova A, Ganeva M, Tsokeva Z, Hadzhibozheva P, Georgiev T, Nancheva $\mathrm{K}$, Vitamin D effects on lipid profile and uric acid levels in the experimental model of metabolic disorders in fructose fed wistar rats. Farmacia, 2019; 67(6): 1071-1076.

4. Navarrete A, Trejo-Miranda JL, Reyes-Trejo L, Principles of root bark of Hippocratea excelsa (Hippocrataceae) with gastroprotective activity. J Ethnopharmacol., 2002; 79(3): 383-388.

5. Pérez RM, Pérez S, Zavala MA, Salazar M, Antiinflammatory activity of the bark of Hippocratea excelsa. J Ethnopharmacol., 1995; 47(2): 85-90.

6. Kim DO, Jeong SW, Lee CY, Antioxidant capacity of phenolic phytochemicals from various cultivars of plums. Food Chem., 2003; 81: 321-326.

7. Mensor LL, Menezes FS, Leitao GG, Reis AS, Dos Santos TC, Coube CS, Leitao SG, Screening of Brazilian plant extracts for antioxidant activity by the use of DPPH free radical method. Phytother Res., 2001; 15: 127-130.

8. Miller NJ, Castelluccio C, Tijburg L, Rice-Evans C, The antioxidant properties of theaflavins and their gallate esters--radical scavengers or metal chelators?. FEBS Lett., 1996; 392(1): 40-44.

9. Landry ML, Stanat S, Biron K, Brambilla D, Britt W, Jokela J, Chou S, Drew WL, Erice A, Gilliam B, Lurain N, Manischewitz J, Miner R, Nokta M, Reichelderfer $\mathrm{P}$, Spector S, Weinberg A, YenLieberman B, Crumpacker C, A standardized plaque reduction assay for determination of drug susceptibilities of cytomegalovirus clinical isolates. Antimicrob Agents Chemother., 2000; 44(3): 688-692.

10. Merino-Aguilar H, Arrieta-Baez D, Jiménez-Estrada M, Magos-Guerrero G, Hernández-Bautista RJ, SusunagaNotario Adel C, Almanza-Pérez, JC, Blancas-Flores G, Román-Ramos R, Alarcón-Aguilar FJ, Effect of fructooligosaccharides fraction from Psacalium decompositum on inflammation and dyslipidemia in rats with fructose-induced obesity. Nutrients, 2014; 6(2): 591-604.

11. Ku HK, Lim HM, Oh KH, Yang HJ, Jeong JS, Kim SK, Interpretation of protein quantitation using the Bradford assay: comparison with two calculation models. Anal Biochem., 2013; 434(1): 178-180.

12. Guzmán-Hernández EA, Villalobos-Molina R, SánchezMendoza MA, Del Valle-Mondragón L, PastelínHernández G, Ibarra-Barajas M, Early co-expression of cyclooxygenase- 2 and renin in the rat kidney cortex contributes to the development of $N(G)$ -
nitro-L-arginine methyl ester induced hypertension. Can J Physiol Pharmacol., 2015; 93(4): 299-308.

13. Ajiboye TO, Raji HO, Adeleye AO, Adigun NS, Giwa OB, Ojewuyi OB, Oladiji AT, Hibiscus sabdariffa calyx palliates insulin resistance, hyperglycemia, dyslipidemia and oxidative rout in fructose-induced metabolic syndrome rats. J Sci Food Agric., 2016; 96(5): 1522-1531

14. Weiland F, Verspohl EJ, Local formation of angiotensin peptides with paracrine activity by adipocytes. J Pept Sci., 2009; 15(11): 767-776.

15. Tenorio-López FA, Zarco-Olvera G, Sánchez-Mendoza A, Rosas-Peralta M, Pastelín-Hernández G, del ValleMondragón L, Simultaneous determination of angiotensins II and 1-7 by capillary zone electrophoresis in plasma and urine from hypertensive rats. Talanta, 2010; 80(5): 1702-1712.

16. Nair AR, Elks CM, Vila J, Del Piero F, Paulsen DB, Francis J, A blueberry-enriched diet improves renal function and reduces oxidative stress in metabolic syndrome animals: potential mechanism of TLR4MAPK signaling pathway. PLoS One, 2014; 9(11): e111976: 1-12.

17. Aebi H, Catalase in vitro. Methods Enzymol., 1984; 105: 121-126.

18. Lawrence RA, Burk RF, Glutathione peroxidase activity in selenium deficient rat liver. Biochem Biophys Res Commun., 1976; 71(4): 952-958.

19. Sun Y, Oberley LW, Li Y, A simple method for clinical assay of superoxide dismutase. Clin Chem., 1988; 34(3): 497-500.

20. Yang M, Liu C, Jiang J, Zuo G, Lin X, Yamahara J, Wang J, Li Y, Ginger extract diminishes chronic fructose consumption-induced kidney injury through suppression of renal overexpression of proinflammatory cytokines in rats. BMC Complement Altern Med., 2014; 14: 174: 1-12.

21. Novelli EL, Diniz YS, Galhardi CM, Ebaid GM, Rodrigues HG, Mani F, Fernandes AA, Cicogna AC, Novelli Filho JL, Anthropometrical parameters and markers of obesity in rats. Lab Animals, 2007; 41(1): 111-119.

22. Mamikutty N, Thent ZC, Sapri SR, Sahruddin NN, Mohd Yusof MR, Haji Suhaimi F, The establishment of metabolic syndrome model by induction of fructose drinking water in male Wistar rats. Biomed Res Int., 2014; 2014: 263897: 1-8.

23. Uchida T, Shimizu M, Sakai Y, Nakano T, Hara K, Takebayashi K, Inoue T, Node K, Inukai T, Takayanagi $\mathrm{K}$, Aso Y, Effects of losartan on serum total and high-molecular weight adiponectin concentrations in hypertensive patients with metabolic syndrome. Metabolism, 2008; 57(9): 1278-1285.

24. Sharieh Hosseini SG, Khatamsaz S, Shariati M, The effects of losartan on memory performance and leptin resistance induced by obesity and high-fat diet in adult male rats. Iran J Basic Med Sci., 2014; 17(1): 41-48.

25. Niranjana Murthy H, Dandin VS, Yoeup Paek K, Hepatoprotective activity of ginsenosides from Panax ginseng adventitious roots against carbon tetrachloride treated hepatic injury in rats. J Ethnopharmacol., 2014; 158(Part A): 442-446.

26. Bulboacă A, Bolboacă SD, Suci S, Protective effect of curcumin in fructose-induced metabolic syndrome 
and in streptozotocin-induced diabetes in rats. Iran J Basic Med Sci., 2016; 19(6): 585-593.

27. Singh D, Arya PV, Sharma A, Dobhal MP, Gupta $\mathrm{RS}$, Modulatory potential of $\alpha$-amyrin against hepatic oxidative stress through antioxidant status in Wistar albino rats. J Ethnopharmacol., 2015; 161: 186-193.

28. Prabhakar P, Reeta KH, Maulik SK, Dinda AK, Gupta YK, $\alpha$-Amyrin attenuates high fructose dietinduced metabolic syndrome in rats. Appl Physiol Nutr Metab., 2017; 42(1): 23-32.

29. Bezerra Carvalho KMM, de Melo TS, de Melo KM, Gomes Quinderé AL, Bandeira de Oliveira FT, Custódio Viana AFS, Gomes Nunes PI, da Silva Quetz J, de Araújo Viana D, de Carvalho Almeida da Silva AA, Havt A, da Cruz Fonseca SG, Chaves MH, Amyrins from Protium heptaphyllum Reduce HighFat Diet-Induced Obesity in Mice via Modulation of Enzymatic, Hormonal and Inflammatory Responses. Planta Med., 2017; 83(03/04): 285-291.

30. Zhang DM, Jiao RQ, Kong LD, High Dietary Fructose: Direct or Indirect Dangerous Factors Disturbing Tissue and Organ Functions. Nutrients, 2017; 9(4): 335: 1-25.

31. Parhofer KG, Increasing HDL-cholesterol and prevention of atherosclerosis: A critical perspective. Atheroscler Suppl., 2015; 18: 109-111.

32. Rabie EM, Heeba GH, Abouzied MM, Khalifa MM, Comparative effects of Aliskiren and Telmisartan in high fructose diet-induced metabolic syndrome in rats. Eur J Pharmacol., 2015; 760: 145-153.

33. Gersch MS, Mu W, Cirillo P, Reungjui S, Zhang L, Roncal C, Sautin YY, Johnson RJ, Nakagawa T, Fructose, but not dextrose, accelerates the progression of chronic kidney disease. Am J Physiol Renal Physiol., 2007; 293(4): F1256-1261.

34. Cho AS, Jeon SM, Kim MJ, Yeo J, Seo KI, Choi MS, Lee MK, Chlorogenic acid exhibits anti-obesity property and improves lipid metabolism in high-fat diet-induced-obese mice. Food Chem Toxicol., 2010; 48(3): 937-943.

35. Mamikutty N, Thent ZC, Sapri SR, Sahruddin NN, Mohd Yusof MR, Haji Suhaimi F, The establishment of metabolic syndrome model by induction of fructose drinking water in male Wistar rats. Biomed Res Int., 2014; 2014: 263897: 1-8.

36. Kawarazaki W, Fujita T, The Role of Aldosterone in Obesity-Related Hypertension. Am J Hypertens., 2016; 29(4): 415-423.

37. Novelli EL, Diniz YS, Galhardi CM, Ebaid GM, Rodrigues HG, Mani F, Fernandes AA, Cicogna AC, Novelli Filho JL, Anthropometrical parameters and markers of obesity in rats. Lab Animals, 2007; 41(1): 111-119.

38. El-Fawal R, El Fayoumi HM, Mahmoud MF, Diosmin and crocin alleviate nephropathy in metabolic syndrome rat model: Effect on oxidative stress and low grade inflammation. Biomed Pharmacother., 2018; 102: 930-937.

39. Jefferson A, Shankland $\mathrm{Sj}$, Pichler RH, Proteinuria in diabetic kidney disease: a mechanistic viewpoint. Kidney Int., 2008; 74(1): 22-36.

40. Ghayur A, Liu L, Kolb M, Chawla A, Lambe S, Kapoor A, Margetts PJ, Adenovirus-mediated gene transfer of TGF-beta1 to the renal glomeruli leads to proteinuria. Am J Pathol., 2012; 180(3): 940-951.

41. Cabandugama PK, Gardner MJ, Sowers JR, The Renin Angiotensin Aldosterone System in Obesity and Hypertension: Roles in the Cardiorenal Metabolic Syndrome. Med Clin North Am., 2017; 101(1): 129-137.

42. Chou CL, Lin H, Chen JS, Fang TC, Renin inhibition improves metabolic syndrome, and reduces angiotensin II levels and oxidative stress in visceral fat tissues in fructose-fed rats. PLoS One, 2017; 10; 12(7): e0180712: 1-17.

43. Rosenbloom J, Castro S, Jimenez SA, Narrative review: fibrotic diseases: cellular and molecular mechanisms and novel therapies. Ann Intern Med., 2010; 152: 159-166.

44. Watanabe D, Tanabe A, Naruse M, Morikawa S, Ezaki T, Takano K, Renoprotective effects of an angiotensin II receptor blocker in experimental model rats with hypertension and metabolic disorders. Hypertens Res., 2009; 32(9): 807-815.

45. Kong X, Zhang DY, Wu HB, Li FX, Losartan and pioglitazone ameliorate nephropathy in experimental metabolic syndrome rats. Biol Pharm Bull., 2011; 34(5): 693-699.

46. Yoshiji H, Fukui H, Renin-angiotensin system and progression of chronic liver diseases. J Gastroenterol., 2006; 41(10): 1020-1022.

47. Sies H, Oxidative stress: oxidants and antioxidants. Exp Physiol., 1997; 82(2): 291-295.

48. Singal PK, Khaper N, Palace V, Kumar D, The role of oxidative stress in the genesis of heart disease. Cardiovasc Res., 1998; 40(3): 426-432.

49. Pérez-Barrón G, Avila-Acevedo JG, García-Bores AM, Montes S, García-Jiménez S, León-Rivera I, Rubio-Osornio M, Monroy-Noyola A, Neuroprotective effect of Buddleja cordata methanolic extract in the 1-methyl-4-phenylpyridinium Parkinson's disease rat model. J Nat Med., 2015; 69(1): 86-93.

50. Ávila Acevedo JG, Espinosa González AM, De Maria y Campos DM, Benítez Flores J del C, Hernández Delgado T, Flores Maya S, Campos Contreras J, Muñoz López JL, García Bores AM, Photoprotection of Buddleja cordata extract against UVB-induced skin damage in SKH-1 hairless mice. BMC Complement Altern Med., 2014; 14: 281: 1-9.

51. Biba Vikas, Akhil B S, Remani P, Sujathan K, Free Radical Scavenging Properties of Annona squamosa. Asian Pac J Cancer Prev., 2017; 18(10): 2725-2732.

52. Chung S, Yoon HE, Kim SJ, Kim SJ, Koh ES, Hong YA, Park CW, Chang YS, Shin SJ, Oleanolic acid attenuates renal fibrosis in mice with unilateral ureteral obstruction via facilitating nuclear translocation of Nrf2. Nutr Metab Lon., 2014; 11(1): 2: 1-11.

53. Son E, Yoon JM, An BJ, Lee YM, Cha J, Chi GY, Kim DS, Comparison among Activities and Isoflavonoids from Pueraria thunbergiana Aerial Parts and Root. Molecules, 2019; 24(5): 912: 1-12.

54. Chung S, Yoon HE, Kim SJ, Kim SJ, Koh ES, Hong YA, Park CW, Chang YS, Shin SJ, Oleanolic acid attenuates renal fibrosis in mice with unilateral ureteral obstruction via facilitating nuclear translocation of Nrf2. Nutr Metab Lon., 2014; 11(1): 2: 1-11. 